\title{
Pengaruh Penerapan Model Moody Terhadap Hasil Belajar Memahami Makna Lirik Lagu Wajib Nasional Pada Siswa Kelas V SD Negeri 1 Sindangbarang Kecamatan Jalaksana Kabupaten Kuningan
}

\author{
Juju Juhaeriah ${ }^{1}$, Dadang Cunandar ${ }^{2}$. \\ STKIP Muhammadiyah Kuningan \\ a_dadang28@upmk.ac.id
}

\section{Info Artikel}

\section{Sejarah Artikel:}

Diterima Bulan Januari, 2020

Dipublikasikan

Bulan Februari, 2020

Kata Kunci: Model

Moody, Hasil

Belajar, lirik Lagu

Wajib Nasional

Keywords: Moody's

Model, Learning

Outcomes, National

Mandatory Song

Lyrics

\section{Abstrak}

Penelitian ini dilatarbelakangi oleh hasil belajar memahami makna lirik lagu siswa kelas $\mathrm{V}$ masih relatif rendah, hal ini berdampak pada rendahnya nilai hasil belajar 22 siswa yaitu sebesar $48,55 \%$, dari jumlah seluruhnya belum mencapai KKM dimana KKM Bahasa Indonesia di SD Negeri 1 Sindangbarang sebagaimana telah ditetapkan yaitu 70. Model Moody dapat dijadikan alternatif yang dapat meningkatkan hasil belajar memahami makna lirik lagu dalam jangka waktu yang lebih panjang. Penelitian ini bertujuan untuk mengetahui Pengaruh Penerapan Model Moody Terhadap Hasil Belajar Memahami Makna Lirik Lagu Wajib Nasional Pada Siswa Kelas V SD Negeri 1 Sindangbarang Kecamatan Jalaksana Kabupaten Kuningan. Desain penelitian ini menggunakan One Group Pretest Posttest Design. Populasi dalam penelitian ini siswa kelas V SD Negeri 1 Sindangbarang yang berjumlah 22 siswa. Pengambilan sampel menggunakan teknik sampling total. Hasil penelitian nilai pretest yaitu 48,55. Hasil penelitian menunjukan terdapat Pengaruh Penerapan Model Moody Terhadap Hasil Belajar Memahami Makna Lirik Lagu Wajib Nasional Pada Siswa Kelas V SD Negeri 1 Sindangbarang Kecamatan Jalaksana Kabupaten Kuningan.

\section{Abstract}

This research is motivated by the results of learning to understand the meaning of song lyrics of class $V$ students is still relatively low, this has an impact on the low value of learning outcomes of 22 students that is equal to $48,55 \%$ of the total has not yet reached the KKM where the Indonesian Language KKM in SD Negeri 1 Sindangbarang as set at 70. Moody's model can be used as an alternative that can improve learning outcomes to understand the meaning of song lyrics in a longer period of time. This study aims to determine the Effect of Moody's Model Application on the Results of Learning to Understanding the Meaning of National Song Lyrics in Class V Students of SD Negeri 1 Sindangbarang, Jalaksana District, Kuningan Regency. The design of this study uses One Group Pretest Posttest Design. The population in this study were fifth grade students of SD Negeri 1 Sindangbarang, totaling 22 students. Sampling uses the Total Sampling technique.. The results showed that there was an effect of the application of the Moody model on Learning Outcomes Understanding the meaning of National Song Lyrics in fifth grade stidents of SD Negeri 1 Sindangbarang, Jalaksana District, Kuningan Regency.
Alamat Korespondensi Email

\author{
: STKIP Muhammadiyah Kuningan \\ : a_dadang28@upmk.ac.id
}

ISSN 2541-6855 (Online) ISSN 2541-0199 (Cetak 


\section{PENDAHULUAN}

Format teks utama terdiri dari kolom kiri-kanan datar di atas kertas A4 (kuarto). Teks margin dari kiri dan atas adalah 2,5 cm, kanan dan bawah adalah 2 cm. Naskah ditulis dalam Microsoft Word, spasi tunggal, TNR 12pt, 2 kolom dan maksimal 12 halaman.

Pendidikan nasional Indonesia bertujuan untuk mengembangkan potensi peserta didik agar menjadi manusia yang beriman dan bertaqwa kepada Tuhan Yang Maha Esa, berakhlak mulia, sehat, berilmu, cakap, kreatif, mandiri dan menjadi warga negara yang demokratis serta bertanggung jawab.Undang-undang Nomor 20 Tahun 2003 Bab II Pasal (3). Untuk mewujudkan tujuan pendidikan nasional tersebut, berbagai usaha telah dilakukan oleh pemerintah, di antaranya adalah pembaharuan sistem pendidikan .Undang-undang No.20 Tahun 2003 Tentang Sisdiknas Pasal 1 ayat 20, pembelajaran merupakan sebuah proses interaksi antara peserta didik dengan pendidik dan sumber belajar dalam suatu lingkungan belajar.

Berdasarkan perkembangan kurikulum yang berlaku di Indonesia, peserta didik sebaiknya juga mempelajari lagu-lagu nasional, namun disayangkan mereka tidak tertarik dengan lagu-lagu nasional. Guru pun kurang memberikan pelajaran lagu-lagu nasional. Salah satu faktor kurangnya motivasi minat pada lagu nasional adalah peserta didik menganggap lagu nasional kurang menarik. Karena kurang diajarkannya lagu Wajib Nasional kepada peserta didik, sehingga menyebabkan peserta didik kurang mengenali dan kurang berminat terhadap musik nasional. Lingkungan sekolah juga kurang mendukung minat peserta didik dalam bermusik. Sayangnya musik hanya untuk kebutuhan hiburan di sekolah saja tidak dikembangkan dengan baik.

Pentingnya pembelajaran apresiasi sastra di sekolah dasar sudah tidak diragukan lagi, mengingat karya sastra merupakan hasil cipta karsa dalam kehidupan manusia di muka bumi ini. Unsur-unsur yang terkandung dalam suatu karya sastra merupakan cerminan dari realitas pergumulan manusia dengan segenap kepentingannya. Materi ajar sastra pun dijadikan sebagai salah satu bagian untuk menuju tercapainya tujuan pendidikan.

Materi sastra di dalam kurikulum dapat dikenali melalui standar isi yang dikembangkan oleh BSNP (Permendiknas No. 22 Th.2006). Di dalam SI terdapat standar kompetensi mata pelajaran bahasa Indonesia yang merupakan kualifikasi kemampuan minimal peserta didik yang digambarkan melalui penguasaan pengetahuan, keterampilan, dan sikap positif terhadap bahasa dan sastra Indonesia. Standar Kompetensi ini merupakan dasar bagi peserta didik untuk memahami dan merespon situasi lokal, regional, nasional, dan global.

Menurut Cunandar (2019: 29), standar kompetensi ini terdapat beberapa harapan yang ditumpukan kepada mata pelajaran bahasa Indonesia, yakni sebagai berikut.

a. Peserta didik dapat mengembangkan potensinya sesuai dengan kemampuan, kebutuhan, dan 
minatnya, serta dapat menumbuhkan penghargaan terhadap hasil karya kesastraan dan hasil intelektual bangsa sendiri;

b. Pendidik dapat memusatkan perhatian kepada pengembangan kompetensi bahasa peserta didik dengan menyediakan berbagai kegiatan berbahasa, bersastra, dan sumber belajar;

c. Pendidik lebih mandiri dan leluasa dalam menentukan bahan ajar kebahasaan dan kesastraan sesuai dengan kondisi lingkungan sekolah dan kemampuan peserta didiknya;

d. Orang tua dan masyarakat dapat secara aktif terlibat dalam pelaksanaan program kebahasaan dan kesastraan di sekolah;

e. Sekolah dapat menyusun program pendidikan tentang kebahasaan dan kesastraan sesuai dengan keadaan peserta didik dan sumber belajar yang tersedia;

f. Daerah dapat menentukan bahan dan sumber belajar kebahasaan dan kesastraan sesuai dengan kondisi dan kekhasan daerah dengan tetap memperhatikan kepentingan nasional.

Bahasa merupakan salah satu unsur terpenting dalam sebuah karya sastra. Berdasarkan pendapat yang diungkapkan oleh Nurgiyantoro dalam Cunandar (2019:29) bahasa dalam seni sastra ini dapat disamakan dengan cat warna, keduanya merupakan unsur bahan, alat, dan sarana yang mengandung nilai lebih untuk dijadikan sebuah karya. Sebagai salah satu unsur terpenting tersebut, maka bahasa berperan sebagai sarana pengungkapan dan penyampaian pesan dalam sastra.

Pembelajaran

bersastra

dikehendaki terjadinya kegiatan bersastra, yaitu kegiatan menggunakan bahasa dan estetika Rusyana dan Suryaman dalam Cunandar (2019:29). Sejalan dengan pernyataan tersebut, esensi dari pembelajaran sastra adalah siswa harus dapat melakukan seperti apa yang dikemukakan Effendi dalam Aminuddin (2015:35) yaitu dapat menggauli karya sastra secara sungguh-sungguh sehingga menumbuhkan pengertian, penghargaan, kepekaan pikiran kritis dan kepekaan perasaan yang baik terhadap karya sastra.

Fungsi utama sastra adalah untuk penghalus budi, peningkatan rasa kemanusiaan dan kepedulian sosial, penumbuh apresiasi budaya, penyaluran gagasan, penumbuhan imajinasi, serta peningkatan ekspresi secara kreatif dan konstruktif. Pembelajaran sastra dalam mata pelajaran bahasa Indonesia bertujuan untuk meningkatkan kemampuan peserta didik dalam menikmati, menghayati, dan memahami karya sastra. Namun, kegiatan bersastra juga belum berkembang secara maksimal karena kemampuan dan kebiasaan membaca dan menulis mereka relatif rendah Kusmana dalam Cunandar (2019:30).

Kenyataan di SD Negeri 1 Sindangbarang, hasil belajar memahami makna lirik lagu dalam mengapresiasi Lagu Wajib Nasional pada siswa sekolah dasar, tepatnya siswa kelas V SD Negeri 1 Sindangbarang Kecamatan Jalaksana Kabupaten Kuningan masih relatif rendah karena siswa kurang memahami makna lirik lagu Wajib Nasional.(Hasil observasi 
awal yang dilakukan pada tanggal 06-15 Februari 2019 dengan guru Bapak Saleh, guru pamong SD Negeri 1 Sindangbarang yaitu bapak Oyo, Guru wali kelas V yaitu Ibu Yansih, dan Zahra siswa kelas V). Rendahnya hasil pembelajaran tersebut terjadi karena siswa merasa sulit dalam mempelajari makna lirik lagu wajib Nasional, akibat keterbatasan sumber ajar sastra, dan pembelajaran yang disajikan guru kurang menarik. Guru masih kurang kreatif dalam menarik minat siswa untuk mengapresiasi Lagu wajib Nasional, selain itu dalam penyampaian makna lirik lagu wajib Nasional masih relatif rendah.

$$
\text { Rendahnya hasil belajar }
$$

memahami makna lirik Lagu Wajib Nasional secara tidak langsung dapat melemahkan identitas bangsa. Jika Lagu Wajib Nasional tidak dikenalkan dan tidak disukai oleh generasi muda, dapat menyebabkan kurangnya rasa nasionalisme terhadap tanah air. Lagulagu nasional semestinya menjadi suatu hal yang dibanggakan, bukan ditinggalkan. Peran serta masyarakat sangat diperlukan dalam memperkuat jati diri bangsa, dan jati diri yang kuat, bangsa indonesia akan semakin bermartabat sehingga mampu berperan bahkan juga bersaing positif dalam kehidupan yang mengglobal. Upaya yang dilakukan untuk mengatasi masalah-masalah tersebut, diperlukan kajian lebih lanjut dengan melihat berbagai faktor yang mempengaruhinya, salah satu faktor yang dipertimbangkan adalah model pembelajaran yang digunakan oleh Guru.

$$
\text { Pada saat pembelajaran }
$$
berlangsung, siswa hanya dapat menyanyikan lagu-lagu wajib Nasional didalam kelas ketika kegiatan pembelajaran akan berlangsung. Kemudian dalam memahami makna lagu wajib Nasional siswa merasa sulit. Fenomena tersebut mengindikasikan adanya faktor kelemahan sistem pembelajaran yang dibangun oleh guru, dan faktor kelemahan siswa yang mayoritas merasa kesulitan dalam memahami makna lagu wajib Nasional. Strategi yang dapat dipakai oleh guru dalam mengurai persoalan tersebut, yaitu dengan cara mengemas pembelajaran sebaik mungkin dengan menggunakan pendekatan, metode, model, serta media yang sesuai dengan kondisi siswa.

Salah satu model pembelajaran yang dapat dipakai dalam pembelajaran Bahasa Indonesia adalah model moody. Model moody merupakan model pengajaran sastra yang diterapkan dalam pembelajaran mengapresiasi cerita pendek. Menurut pendapat Sapardan dalam Cunandar (2019:30) menunjukan enam tahapan penyajian pengajaran sastra yang dapat diterapkankan dalam mengapresiasi cerita pendek, yakni preliminary assessment (pelacakan awal), practical decision (menentukan sikap praktis), introduction of the work (introduksi), presentation of the work (penyajian karya), discussion (diskusi), reinforcement (pengukuhan).

Model Moody kiranya cocok untuk mengatasi kesulitan siswa dalam memahami makna lirik Lagu Wajib Nasional. Berdasarkan latar belakang masalah yang dikemukakan diatas, penulis mencoba mengadakan penelitian yang berhubungan dengan hal tersebut dengan mengajukan judul "Pengaruh 
Penerapan Model Moody terhadap Hasil Belajar Memahami Makna Lirik Lagu Wajib Nasional pada Siswa Kelas V SD Negeri 1 Sindangbarang”

\section{METODE PENELITIAN}

Dalam penelitian ini, peneliti menggunakan metode pendekatan PreExperimental Designs (nondesigns). Sebagaimana menurut pendapat Sugiyono (2017:109) dikatakan PreExperimental Designs karena desain ini belum merupakan eksperimen sungguhsungguh, karena masih terdapat variabel luar yang ikut berpengaruh terhadap terbentuknya variabel dependen. Jadi hasil eksperimen yang merupakan variabel dependen itu bukan semata-mata dipengaruhi oleh variabel independen. Hal ini dapat terjadi, karena tidak adanya variabel kontrol, dan sampel tidak dipilih secara random.

Desain penelitian yang digunakan dalam penelitian ini, peneliti menggunakan jenis metode PreExperimental Designs dengan rancangan one group pretest-postest Design, karena peneliti ingin mengetahui pengaruh perlakuan yang diberikan terhadap objek. Bentuk perlakuan sebagai variabel bebas dan objek yang mengalami perlakuan sebagai variabel terikat. Artinya bahwa ingin melihat pengaruh variabel bebas (perlakuan) terhadap objek (variabel terikat).

Menurut Sugiyono (2017: 110) desain ini dapat digambarkan sebagai berikut.$$
\mathrm{O}_{1} \mathrm{X} \mathrm{O}_{2}
$$

Gambar 1. Desain Penelitian

Keterangan :

O1:Nilai pretest (sebelum menggunakan model Moody)

O2:Nilai posttest (setelah menggunakan model Moody)

Pengaruh Model Moody terhadap Hasil

Belajar Memahami Makna Lirik Lagu Wajib Nasional

Pada penelitian ini peneliti mengambil 1 kelas yang diteliti untuk dijadikan sampel dengan jumlah 22 siswa kelas V SD Negeri 1 Sindangbrang kecamatan Jalaksana Kabupaten Kuningan. Instrumen pengumpulan data menggunakan observasi, tes dan dokumentasi.

Teknik analisis data menggunakan pengujian persyaratan analisis, uji normalitas, uji homogenitas, dan uji linearitas serta uji hipotesis t.

\section{HASIL PENELITIAN DAN \\ PEMBAHASAN}

Pada bagian ini dijelaskan hasil-hasil penelitian dalam bentuk paragraf-paragraf sekaligus diberikan pembahasan yang komprehensif. Hasil dapat disajikan dalam bentuk gambar, grafik, tabel dan lain-lain yang memudahkan pembaca.

1. Hasil belajar memahami makna lirik Lagu Wajib Nasional pada siswa kelas $V$ SD Negeri 1 Sindangbarang Kecamatan Jalaksana Kabupaten Kuningan dalam menelusuri unsur Intrinsik Lagu sebelum menggunakan model pembelajaran Moody.Berdasarkan data hasil pretest hasil belajar memahami makna lirik Lagu Wajib Nasional pada siswa kelas 
V SD Negeri 1 Sindangbarang Kecamatan Jalaksana Kabupaten Kuningan sebelum menerapkan model pembelajaran Moody penulis memuatkan tabel frekuensi sebagai berikut.

Tabel 4.9

Frekuensi Data Pretest Hasil Belajar Memahami Mankna Lirik Lagu Wajib Nasional Pada Siswa Kelas V SD Negeri 1 Sindangbarang Sebelum Menerapkan Model Moody

\begin{tabular}{|c|c|c|c|c|}
\hline \multicolumn{5}{|c|}{ Pretest } \\
\hline & $\begin{array}{l}\text { requenc } \\
y\end{array}$ & $\begin{array}{l}\text { ercen } \\
t\end{array}$ & \begin{tabular}{|l|} 
alid \\
Perce \\
$n t$
\end{tabular} & $\begin{array}{l}\text { umulati } \\
\text { ve } \\
\text { ercent }\end{array}$ \\
\hline \begin{tabular}{|rr}
$a l i$ & 2 \\
$d$ & \\
\end{tabular} & 2 & 9,1 & 9,1 & 9,1 \\
\hline 5 & 2 & 9,1 & 9,1 & 18,2 \\
\hline j & 3 & 13,6 & 13,6 & 31,8 \\
\hline 8 & 4 & 18,2 & 18,2 & 50,0 \\
\hline 2 & 5 & 22,7 & 22,7 & 72,7 \\
\hline 5 & 3 & 13,6 & 13,6 & 86,4 \\
\hline 4 & 3 & 13,6 & 13,6 & 100,0 \\
\hline Total & 22 & 00,0 & 100,0 & \\
\hline
\end{tabular}

Berdasarkan tabel 4.12 siswa yang memperoleh nilai 32 sebanyak 2 orang $(9,1 \%)$, nilai 36 sebanyak 2 orang $(9,1 \%)$, nilai 40 sebanyak 3 orang $(13,6 \%)$, nilai 48 sebanyak 4 orang $(18,2 \%)$, nilai 52 sebanyak 5 orang $(22,7 \%)$, nilai 56 sebanyak 3 orang $(13,6 \%)$, dan yang memperoleh nilai 64 sebanyak 3 orang $(13,6 \%)$. Nilai rata-rata yang diperoleh adalah 48,55.

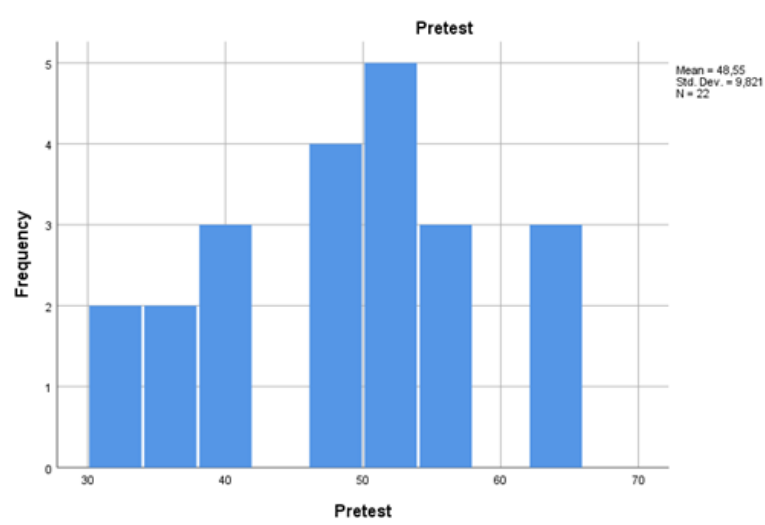

\section{Gambar 4.1 Nilai Hasil Pretest}

Dari data pretes dapat disimpulkan bahwa hasil belajar memahami makna lirik Lagu Wajib Nasional pada siswa kelas V SD Negeri 1 Sindangbarang Kecamatan Jalaksana Kabupaten Kuningan sebelum menerapkan Model Moody masih rendah. Rendahnya hasil belajar siswa disebabkan oleh pembelajaran disekolah yang masih dilakukan secara konvensional, dalam proses pembelajaran guru hanya menggunakan metode ceramah, diskusi dan penugasan. Dalam penyampaian materi khususnya tentang Apresiasi karya sastra dengan materi pokok Puisi Bebas tentang belajar memahami makna lirik lagu Wajib Nasional Guru menyampaikan pembelajaran secara verbal, hal tersebut menyebabkan kurangnya partisifasi aktif siswa dalam pembelajaran yang berkaitan langsung dengan Apresiasi karya sastra. Secara tradisional guru sastra sering bertindak sebagai penyalur informasi langsung kepada siswa dan siswa menerima informasi secara pasif. Dengan demikian, siswa mendapat pengetahuan bukan dari sumber yang sebenarnya, yaitu karya sastra yang menjadi materi pembelajaran. Dalam pengajaran sastra, cara-cara seperti itu seharusnya tidak perlu terjadi sebab 
menurut Moody Rahmanto dalam Rohmah (2017:73) pengajaran sastra tidak dimaksudkan untuk membentuk aktivitas mekanis atau otomatis tanpa membawa siswa terlibat masuk ke dalam karya sastra yang sedang dipelajarinya. Sifat dasar karya sastra hanya dapat diserap siswa dengan baik apabila setiap unsur khusus dihadirkan sebagai suatu pengalaman baru bagi siswa.

Dengan kata lain, pengajaran sastra menuntut keterlibatan dan partisifasi siswa secara aktif dan secara langsung terhadap objek yang dipelajarinya. Dalam hal ini siswa perlu dihadapkan langsung pada karya sastra yang menjadi acuan pembelajaran apresiasi sastra. Keharusan tersebut sesuai dengan sifat dasar karya sastra yang baru bisa dipahami dan dinikmati dengan baik apabila kita terlibat secara langsung.

1. Hasil Belajar memahami makna lirik Lagu Wajib Nasional pada siswa kelas V SD Negeri 1 Sindangbarang Kecamatan Jalaksana Kabupaten Kuningan dalam menelusuri unsur Intrinsik Lagu setelah menggunakan model pembelajaran Moody.

Berdasarkan data hasil postest hasil belajar memahami makna lirik Lagu Wajib Nasional pada siswa kelas V SD Negeri 1 Sindangbarang Kecamatan Jalaksana Kabupaten Kuningan setelah menggunakan model pembelajaran Moody penulis memuatkan tabel frekuensi sebagai berikut.

\section{Tabel 4.10}

Frekuensi Data Posttest Hasil Belajar Memahami Mankna Lirik Lagu Wajib Nasional pada Siswa Kelas V SD Negeri 1 Sindangbarang Sebelum Menerapkan Model Moody

\section{Postttest}

\begin{tabular}{|c|c|c|c|c|}
\hline & $\begin{array}{l}\text { equenc } \\
y\end{array}$ & ercen & $\begin{array}{l}\text { alid } \\
\text { Perce } \\
n t\end{array}$ & $\begin{array}{l}\text { umulati } \\
\text { ve } \\
\text { ercent }\end{array}$ \\
\hline $\begin{array}{ll}a l i & 3 \\
d & \end{array}$ & 3 & 13,6 & 13,6 & 13,6 \\
\hline 2 & 2 & 9,1 & 9,1 & 22,7 \\
\hline 5 & 8 & 36,4 & 36,4 & 59,1 \\
\hline$\rho$ & 6 & 22,7 & 22,7 & 86,4 \\
\hline$\beta$ & 3 & 13,6 & 13,6 & 100,0 \\
\hline Total & 22 & 00,0 & 100,0 & \\
\hline
\end{tabular}

Berdasarkan tabel 4.11 siswa yang memperoleh nilai 68 sebanyak 3 orang $(13,6 \%)$, siswa yang memperoleh nilai 72 sebanyak 2 orang $(9,1 \%)$, siswa yang memperoleh nilai 76 sebanyak 8 orang $(36,4 \%)$, siswa yang memperoleh nilai 80 sebanyak 6 orang $(27,3 \%)$ dan yang memperoleh nilai 88 sebanyak 3 orang $(13,6 \%)$. Nilai rat-rata yang diperoleh adalah 77,27.

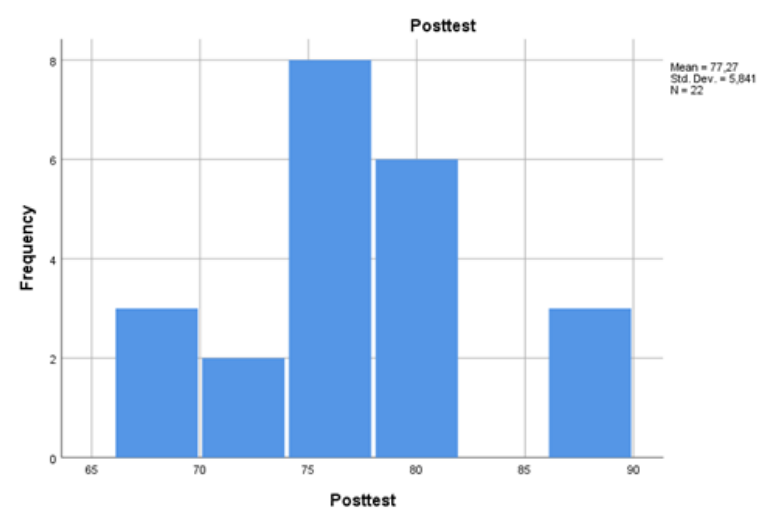

Gambar 4.2 Nilai Hasil Posttest

Dari data Posttest dapat disimpulkan bahwa hasil belajar memahami makna lirik Lagu Wajib Nasional pada siswa kelas V SD Negeri 1 Sindangbarang Kecamatan Jalaksana Kabupaten Kuningan setelah menerapkan Model Moody meningkat. Peningkatan Hasil belajar siswa disebabkan oleh pembelajaran dengan 
menerapkan Model Moody. Dalam penyampaian materi khususnya tentang Apresiasi karya sastra dengan materi pokok Puisi Bebas tentang belajar memahami makna lirik lagu Wajib Nasional Guru menuntut siswa untuk belajar sastra secara langsung tersebut menyebabkan partisifasi aktif siswa dalam pembelajaran yang berkaitan langsung dengan Apresiasi karya sastra tentang materi memahami makna lirik Lagu Wajib Nasional Dengan demikian, siswa mendapat pengetahuan langsung dari sumber yang sebenarnya, yaitu karya sastra yang menjadi materi pembelajaran. Dalam pengajaran sastra, cara-cara ini perlu ditingkatkan dengan membawa siswa terlibat masuk ke dalam karya sastra yang sedang dipelajarinya. Sifat dasar karya sastra hanya dapat diserap siswa dengan baik apabila setiap unsur khusus dihadirkan sebagai suatu pengalaman baru bagi siswa.

Dengan demikian penerapan model pembelajaran Moody dapat meningkatkan hasil belajar memahami makna lirik Lagu Wajib Nasional pada siswa kelas V SD Negeri 1 Sindangbarang Kecamatan Jalaksana Kabupaten Kuningan dalam menelusuri unsur Intrinsik Lagu. Hal ini berarti bahwa pengajaran sastra menuntut keterlibatan siswa secara aktif dan secara langsung terhadap objek yang dipelajarinya. Dalam hal ini siswa perlu dihadapkan pada karya sastra yang menjadi acuan pembelajaran apresiasi sastra. Keharusan tersebut sesuai dengan sifat dasar karya sastra yang baru bisa dipahami dan dinikmati dengan baik apabila kita terlibat secara langsung. Lebih tegas lagi, Moody, Rahmanto dalam Rohmah (2017:75) memaparkan bahwa pengalaman pada dasarnya lebih merupakan suatu hal yang kita peroleh daripada suatu yang diajarkan kepada kita.

Salah satu model pembelajaran yang dapat dipakai dalam pembelajaran Bahasa Indonesia adalah model Moody, Wardani (2016:50) menunjukan enam tahapan penyajian pengajaran sastra yang dapat diterapkankan dalam mengapresiasi karya sastra, yakni prelimary assessment (pelacakan awal), practical decision (menentukan sikap praktis), introkduction of the work (introduksi), presentation of the work (penyajian karya), discussion (diskusi), reinforcement (pengukuhan).

Dengan begitu model moody cocok untuk mengatasi kesulitan siswa dalam memahami makna lirik Lagu wajib Nasional, karena lirik lagu Wajib Nasional merupakan bagian dari sebuah unsur instrinsik puisi/ larik yang masuk kedalam Apresiasi Karya Sastra. Pada akhirnya hasil pembelajarannya pun menunjukan peningkatan.

2. Keterlaksanaan belajar memahami makna lirik Lagu Wajib Nasional pada siswa kelas V SD Negeri 1 Sindangbarang Kecamatan Jalaksana Kabupaten Kuningan .

Berdasarkan data hasil lembar observer kegiatan Guru dan siswa selama proses belajar memahami makna lirik Lagu Wajib Nasional menerapkan model Moody diatas, hasil belajar memahami makna lirik Lagu Wajib Nasional menerapkan model Moody dalam pengamatan guru dan siswa mengajar sudah mencapai nilai 91,7 \% terlaksana dengan sangat baik. Secara keseluruhan proses pembelajaran yang dilakukan oleh guru sudah baik, hanya saja masih ada beberpa kendala yang terjadi pada saat guru melaksanakan pembelajaran 
tersebut. Sejalan dengan hal diatas Arifin (2013: 294) mengemukakan keberhasilan pembelajaran banyak dipengaruhi oleh berbagai faktor. Salah satunya adalah faktor guru dapat melaksanakan pembelajaran. Untuk itu, dalam melaksanakan pemebelajaran, guru harus berpijak pada tujuh prinsip pembelajaran yaitu: perhatian dan motivasi, keaktifan, keterlibatan langsung/ berpengalaman, pengulangan, tantangan, balikan dan penguatan, dan perbedaan individual.

Diantara beberapa kendala yang terjadi pada proses pembelajaran yaitu ada beberapa Siswa yang kurang menyimak penjelasan guru dalam menjelaskan pembelajaran apresiasi sastra dengan menggunakan model Moody dan ada beberapa Siswa yang kurang mendiskusikan rumusan masalah dalam bentuk pertanyaan seputar lirik lagu wajib nasional. Disamping itu, ada beberapa siswa yang kurang fokus dalam kegiatan belajar selama dikelas dengan alasan karena sedang menjalankan ibdah puasa. dalam mendiskusikan rumusan masalah dalam bentuk pertanyaan seputar lirik lagu wajib nasional siswa masih sedikit terkesan malumalu dalam kegiatan belajar terlebih karena kegiatan belajar berada pada waktu menjelang siang ini mengakibatkan siswa kurang fokus dalam belajar, sehingga pada tahap ini guru kurang kondusif dalam menjelaskan tahap pembelajaran tersebut.

Hal ini terjadi karena perbedaan individual siswa yang tidak dapat disamaratakan dengan siswa satu dan siswa yang lainya, sejalan dengan pendapat Arifin (2013:296) mengemukakan, setiap peserta didik memiliki perbedaan satu dengan yang lain. Perbedaan itu terdapat pada karakteristik psikis, kepribadian dan sifatsifatnya, perbedaan individual ini dapat berpengaruh pada cara dan hasil belajar peserta didik.

4. Pengaruh penerapan model Moody terhadap hasil belajar memahami makna lirik Lagu Wajib Nasional pada siswa kelas V SD Negeri 1 Sindangbarang Kecamatan Jalaksana Kabupaten Kuningan dalam menelusuri unsur Intrinsik Lagu.

Berdasarkan perhitungan uji normalitas data pretest diperoleh nilai signifikasi sebesar 0,079 $<0,05$ maka data berdistribusi normal, sedangkan uji normalitas data posttest diperoleh nilai signifikasi sebesar 0,079<0,05 maka dapat disimpulkan data berdistribusi normal.

Dari hasil perhitungan uji homogenitas diperoleh nilai signifikasi sebesar $0,001<0,05$ maka dapat disimpulkan data pretest dan posttes mempunyai variansi yang tidak homogen. Karena data berdistribusi normal dan tidak homogen maka pengujian hipotesis menggunakan uji Wilcoxon.

Berdasarkan perhitungan uji hipotesis secara statistik diperoleh nilai signifikasi $0,000<0,05$ maka $\mathrm{H}_{1}$ diterima dan menolak $\mathrm{H}_{0}$, artinya terdapat perbedaan signifikan terhadap hasil belajar 22 siswa kelas V SD Negeri 1 Sindangbarang terhadap peningkatan hasil belajar memahami makna lirik lagu Wajib Nasional pada kelas $\mathrm{V} \quad$ SDN 1 Sindangbarang Kecamatan Jalaksana Kabupaten Kuningan dengan menerapkan model pembelajaran Moody. Hal ini menunjukan bahwa adanya Pengaruh penerapan model Moody terhadap hasil belajar memahami makna lirik Lagu Wajib Nasional pada siswa kelas V SD Negeri 1 
Sindangbarang Kecamatan Jalaksana Kabupaten Kuningan dengan nilai Posttest lebih baik dari nilai Pretest. dalam menelusuri unsur Intrinsik Lagu.

Hasil penelitian yang menunjukkan bahwa terdapat Pengaruh penerapan model Moody terhadap hasil belajar memahami makna lirik Lagu Wajib Nasional pada siswa kelas V SD Negeri 1 Sindangbarang Kecamatan Jalaksana Kabupaten Kuningan dalam menelusuri unsur Intrinsik Lagu relevan dengan hasil penelitian yang dilakukan oleh Cunandar (2019) Pengaruh Penerapan Model terhadap kemampuan memahami isi cerita rakyat di SD, menyimpulkan bahwa terdapat pengaruh penggunaan model pembelajaran Moody terhadap Kemampuan siswa kelas IV dalam menelusuri unsur struktur cerita rakyat.

\section{SIMPULAN}

Berdasarkan hasil pengolahan data dan pembahasan tentang pengaruh penerapan model Moody terhadap hasil belajar memahami makna lirik lagu Wajib Nasional pada siswa kelas V SD Negeri 1 Sindangbarang Kecamatan Jalaksana Kabupaten Kuningan dalam menelusuri unsur intrinsik lagu, maka penulis menarik kesimpulan sebagai berikut.

1. Hasil belajar memahami makna lirik Lagu Wajib Nasional pada siswa kelas $\mathrm{V}$ SD Negeri 1 Sindangbarang Kecamatan Jalaksana Kabupaten Kuningan dalam menelusuri unsur intrinsik lagu sebelum menggunakan model Moody, rendah dengan nilai ratarata 48,55.

2. Hasil belajar memahami makna lirik Lagu Wajib Nasional pada siswa kelas $\mathrm{V}$ SD Negeri 1 Sindangbarang Kecamatan Jalaksana Kabupaten
Kuningan dalam menelusuri unsur intrinsik lagu setelah menggunakan model Moody, meningkat dengan nilai rata-rata 77,27.

3. Keterlaksanaan pembelajaran memahami makna lirik Lagu Wajib Nasional pada siswa kelas V SD Negeri 1 Sindangbarang Kecamatan Jalaksana Kabupaten Kuningan dalam menelusuri unsur intrinsik lagu setelah menggunakan model Moody, sudah terlaksana dengan baik dengan nilai persentase yaitu $91,7 \%$.

4. Terdapat pengaruh penerapan model Moody terhadap hasil belajar memahami makna lirik Lagu Wajib Nasional pada siswa kelas V SD Negeri 1 Sindangbarang Kecamatan Jalaksana Kabupaten Kuningan dalam menelusuri unsur Intrinsik Lagu dengan nilai signifikasi $0,000<0,05$.

\section{DAFTAR PUSTAKA}

Abidin, Yunus. 2015. Pembelajaran Bahasa Berbasis Pendidikan Karakter. Bandung: PT Replika Aditama

Afandi, Muhammad. 2013. Model dan Metode Pembelajaran diSekolah. Semarang: UNISSSULA Press

Aminuddin.2015. Pengantar Apresiasi Karya Sastra. Bandung: Sinar Baru Algesindo
Arifin, Zainal.2013. Evaluasi Pembelajaran.Bandung: PT.Remaja Rosdakarya.

Aritonang, Keke T. 2008. Minat Dan Motivasi Dalam Meningkatkan Hasil Belajar Siswa. Jurnal Pendidikan Penabur-No.10/Tahun ke-7/Juni 2008. Jakarta : Guru SMPK 1 Bpk Penabur. Diakses tanggal 21 februari 2019, jam $\quad 14.00 \quad$ WIB, dari: https://www.academia.edu>minat_dan_mo tivasi_dalam_meningkatkan_hasil_belajar _siswa. Pdf.

Clarencia, Chiquita. 2018. Jenis-Jenis Makna Dari Lirik-Lirik Lagu Terlaris Boyband VIXX. Jurnal Skripsi. Universitas SAM Ratulangi Fakultas Ilmu Budaya Manado. Diakses tanggal 21 februari 2019, jam 14.00 WIB, 
Jurnal Lensa Pendas, Vol. 5 Nomor 1 , 2020, HIm 7-18

Juju Juhaeriah ${ }^{1}$, Dadang Cunandar ${ }^{2}$

dari: $\quad$ https://ejournal.unsrat.ac.id $>$ article.

Pdf.

Cunandar, Dadang.2017.Buku Pedoman Penyusunan Proposal dan Penulisan Skripsi. STKIP Muhammadiyah Kuningan: Lembaga Pengembangan Riset dan Teknologi.

Cunandar,Dadang.2019.Pengaruh Penerapan Model Moody Terhadap Kemampuan Siswa Kelas IV SD Dalam Memahami Isi Cerita. Jurnal Lensa Pendas Volume 4 Nomor 1, Februari 2019, Hal 28-35. STKIP Muhammadiyah Kuningan: Jurnal Lensa Pendas. Diakses tanggal 29 februari 2019, jam $\quad 12.10 \quad$ WIB, dari: https://jurnal.upmk.ac.id/index.php/lensape ndas/article/view/484.Pdf

Daryanto. 2012. Model Pembelajaran Inovatif. Yogyakarta: Gava Media

Desternedi dkk. 2005. Meningkatkan Kemampuan Menyanyikan Lagu Wajib Nasionak Dengan Metode Solfegio di Sekolah Dasar. Jurnal PGSD FKIP Universitas Jambi ISBN 978-602-70471-2-9. Seminar Nasional Pendidikan PGSD UMS \& HDPGSDI Wilayah Jawa. Jambi : PGSD FKIP Universitas Jambi. Diakses tanggal 28 februari 2019, jam 18.10 WIB, dari: https://online-journal.unja.ac.id>view.Pdf.

Ditjen Dikdasmen. 2003. Undang-undang RI Nomor 20 Tahun 2003 Tentang Sistem Pendidikan Nasional. Jakarta: Ditjen Dikdasmen. Diakses tanggal 29 februari 2019, jam 12.10 WIB, dari: https://kelembagaan.ristekdikti.go.id.Pdf.

Djamarah dkk.2010.Strategi Belajar Mengajar. Jakarta : Rineka Cipta

Djojosuroto, Kinayati. 2006. Pengajaran Puisi, Analisis dan Pemahamannya. Bandung: Nuansa.

Faizi, Mastur. 2013.Ragam Metode Mengajar Eksakta Pada Murid. Jogjakarta: Diva Press

Gunawan, Indra.2016. Melalui Metoden Direct Instruction Berbantuan Media Audio Visual Dapat Meningkatkan Rasa Cinta Tanah Air dan Keterampilan Menyanyikan Lagu Wajib Dikelas IV SD Negeri 2 Cilongok Kecamatan Cilongok Kabupaten Banyumas.Jurnal FKIP UMP, 2016 Universitas Purwokerto. Diakses tanggal 28 februari 2019, jam 16.14 WIB, dari: prosiding.upgris. ac.id $>$ view $>2428$.Pdf

Hartini, dkk.2017.Peran Lagu Wajib Nasional" Bagimu Negeri" Dalam Implementasi Pembelajaran Karakter Siswa Sekolah Dasar. ELSE (Elementary School Education Journal): Jurnal Pendidikan dan Pembelajaran Sekolah Dasar Volume 1 Nomor 2a Desember 2017 P-ISSN: 25811800 E-ISSN: 2597-4122. Prodi PGSD Fakultas Ilmu Pendidikan Universitas PGRI Madiun . Diakses tanggal 28 februari 2019, jam 10.32 WIB, dari: https://journal.um-

surabaya.ac.id/index.php/pgsd/article/dow nload/1040/723..Pdf

Indrawati. 2011. Modul Pembelajaran Fisika: Model-Model Pembelajaran Implementasinya dalam Pembelajaran Fisika. Jurnal Kementrian pendididkan Dan Kebudayaan Universitas Jember Fakultas Keguruan Dan Ilmu Pendidikan Jember, Juli 2011. Jember: PMIPA FKIP Universitas Jember. Diakses tanggal 28 februari 2019, jam 17.29 WIB, dari: https://repository.unej.ac.id>handle.Pdf.

Khusnul Khotimah. 2016 . Pengaruh Strategi Pembelajaran Terhadap Hasil Belajar Ditinjau Dari Aktifitas Belajar.Surakarta Diakses tanggal 29 februari 2019, jam 15.49 WIB, dari: eprints.ums.ac.id.Pdf.

Komariah, Elynda.2017. Hubungan Kebiasaan Membaca Dengan Hasil Belajar Bahasa Indonesia Pada Siswa Kelas IV SDN Dukuhbadag. Skripsi Program Studi Pendidikan Sekolah Dasar.Kuningan: STKIP Muhammadiyah Kuningan.

Kusmana, Suherli. 2010. Pembelajaran Bahasa Indonesia yang Cerdas dan Kreatif.Ciamis: APBI Mandiri Press.

Massi, Grace. 2014. Analisis Unsur-Unsurr Struktur Batin Beberapa Puisi Dalam Antalogi Puisi "Jakarta Berlin". Jurnal Skripsi. Universitas SAM Ratulangi Fakultas Ilmu Budaya Manado. Diakses tanggal 28 februari 2019, jam 16.14 WIB, dari: https://media.neliti.com>publications.Pdf

Murtono, Sri, dkk.2005. Kerajinan Tangan dan Kesenian. Jakarta: Yudhistira.

Nurgiyantoro, Burhan.2010. Teori Pengkajian Fiksi.Yogyakarta: Gadjah Mada University Press 
Nurgiyantoro, Burhan.2010. Penilaian Pembelajaran Bahasa. Yogyakarta: BPFEYogyakarta

Pateda, Mansoer.2010. Semantik Leksikal. Jakarta: PT Rineka Cipta

Permana, Yudi. 2015. Model-Model Pembelajaran IPS di Sekolah Dasar. Mengembangkan Profesional Guru. Bandung : UPI Press

Printina, Brigida Intan.2017. Strategi Pembelajaran Sejarah Berbasis Lagu-lagu Perjuangan Dalam Kontekks Kesadaran Nasionalisme. Jurnal Agastya Vol 7 No 1 Januari 2017. Jurusan Pendidikan Sejarah FKIP Universitas Sanata Dharma Yogyakarta. Diakses tanggal 29 februari 2019, jam 13.14 WIB, dari: ejournal.inipma.ac.id $>$ article $>$ view.Pdf.

Purnomo, Agus dkk.2016.Pengembangan Aplikasi Info Lagu Nusantara Berbasis Android untuk melestarikan Warisan Budaya Indonesia.Jurnal SIMETRIS, Vol 7 No 2 November 2016 ISSN: 2252-4983. Fakultas MIPA, Program Studi D3 Teknik Informatika Universitas Sebelas Maret. Diakses tanggal 28 februari 2019, jam $16.14 \quad$ WIB, dari: jurnal.umk.ac.id>simet>article>view.Pdf.

Rahmanto,B. 1995. Metode Pengajaran Sastra. Yogyakarta: Kanisius

Rohmah, Ai Nur. 2017. Pengarauh Penerapan Model Moody Terhadap Kemampuan Memahami Isi Cerita Pada Siswa Kelas IV SD Negeri 2 Karoya Kecamatan Cipicung Kabupaten Kuningan. Skripsi Program Studi Pendididkan Guru Sekolah Dasar. Kuningan: STKIP Muhammadiyah Kuningan

Rusmawan dkk.2009.Ilmu Pengetahuan Sosial 5 Untuk Sekolah Dasar \& Madrasah Ibtidaiyah Kelas 5.Jakarta : Pusat Perbukuan, Departemen Pendidikan Nasional.

Rusyana, Yus. (2000). Prasa Tradisional : Pengertian, Klasifikasi, dan teks. Jakarta: Pusat Bahasa Departemen Pendidikan Nasional.

Rusyana, Yus. dan M. Suryaman. (2004). Pedoman Penulisan Buku Pelajaran Bahasa dan Sastra Indonesia SD, SMP, dan SMA. Jakarta: Pusat Perbukuan Departemen Pendidikan Nasional
Saleh.2011.Hubungan Kompetensi Pedagogik Guru Dengan Efektivitas Pembelajaran Pada Mts PUI Cikaso.Skripsi Program Studi Agama Islam.Kuningan: Sekolah Tinggi Islam Al-Ihya.

Sapardan, Dadang Ahmad.2005. Penerapan Model Respons Analisis \& Model Moody dalam Pembelajaran Apresiasi Cerita Pendek. Bandung:UPI

Shoimin, Aris. 2014. 68 Model Pembelajaran Inovatif dalam Kurikulum 2013. Yogyakarta: AR Ruzz Media

Simanjuntak, W.S.2007. Indonesiaku Persadaku Dengan Rangkaian Lagu-lagu Wajib Lagulagu Daerah Dilengkapi Dengan Akrod Gitar. Jakarta: Cv Titik Terang

Siregar, Eveline. 2010. Teori Belajar dan Pembelajaran. Bogor: Ghalia Indonesia

Soemanto, Wasty. 1990. Psikologi Pendidikan. Jakarta: Penerbit PT Ganindo

Subana,M. 2011. Starategi Belajar Mengajar Bahasa Indonesia Berbagai Pendekatan, Metode, Teknik, dan Media Pengajaran. Bandung: Cv Pustaka Setia

Sugiyono. 2017. Metode Penelitian Pendidikan Pendekatan Kuantitatif, Kualitatif, dan $R \& D$. Bandung: Cv Alfabeta

Sugiyono. 2017. Statistika Untuk Penelitian. Bandung: Cv Alfabeta

Supriatun. Pedoman Nasah Porto Folio Karya Seni Monumental Pertunjukan. Jakarta:Depdiknas. 2008. Diakses tanggal 28 februari 2019, jam 16.14 WIB, dari: https://scribd.com>doc > pedoman >naskah> por to folio $>$ karya seni $>$ monumental.

Suprihatin, Titin. 2017. Pengaruh Metode Pembelajaran PQRST (Preview, Question, Read, Summary, dan Test) terhadap Kemampuan Membaca Pemahaman Cerita Rakyat Siswa Kelas V SD Negeri 2 Sindangbarang Kecamatan Jalaksana Kabupaten Kuningan.Skripsi Program Studi Pendidikan Guru Sekolah Dasar. Kuningan: STKIP Muhammadiyah Kuningan.

Sutarna, Nana. 2016. Pendidikan Karakter Siswa Sekolah Dasar Dalam Prespektif Islam. Kuningan :Upmk Press

Tatang.2012. Ilmu Pendidikan. Bandung: Pustaka Setia 
Jurnal Lensa Pendas, Vol. 5 Nomor 1 , 2020, HIm 7-18

Juju Juhaeriah ${ }^{1}$, Dadang Cunandar ${ }^{2}$

Tonggengbio, Christien. 2014. Pengembangan Tema Cinta Dalam Lirik-lirik Lagu Eisblume. Jurnal Kementrian Pendidikan Dan Kebudayaan Universitas SAM Ratulangi Fakultas Ilmu Budaya 2014. Diakses tanggal 28 februari 2019, jam $16.14 \quad$ WIB, dari: prosiding.upgris.ac.id $>$ view $>2428$.Pdf

Toyiba, Fitriyani dkk. Pengaruh Strategi Pembelajaran Aktif Terhadap Hasil Belajar Pada Madrasah Ibtidaiyah. Jurnal Program Studi Pendidikan Guru Madrasah Ibtidaiyah. Fakultas Agama Islam Universitas Muhammadiyah Sidoarjo. Diakses tanggal 28 februari 2019, jam 16.14 WIB, dari: eprints.umsida.ac.id.Pdf

Trianto. 2007. Model-Model Pembelajaran Inovatif Berorientasi Konstruktivistik. Jakarta : Prestasi Pustaka.

Wardani, Ventiana Nervi. 2016. Keefektifan Model Sinektik Dan Model Moody Dalam Pembelajaran Menyusun Teks Cerita Fabel Berbantuan Media Gambar Pada Peserta Didik kelas VIII Sekolah Menengah Pertama. Jurnal Skripsi Fakultas Bahasa dan Seni. Semarang :UNNES Press. Diakses tanggal 28 februari 2019, jam 16.14 WIB, dari: lib.unnes.ac.id.Pdf

Widodo, Wahyu dkk. 2015. Pendidikan Kewarganegaraan Pengantar Teori. Yogyakarta: CV.Andi Offeset

Yamin, Sopyan dkk. 2014. SPSS Complete Teknik Analisis Statistik Terlengkap Dengan Software SPSS. Jakarta: Salemba Infotek. 